\title{
REALITAS PENYIMPANGAN SOSIAL DALAM KONTEKS \\ CYBER SEXUAL HARRASMENT PADA JEJARING SOSIAL LIVE STREAMING \\ BIGO LIVE
}

\author{
Abdul Munir, M.Krim \& Riki Harianto,S.Sos
}

\begin{abstract}
live streaming is a latest innovation for people to express themselves and exchange ideas. The current social media that is becoming a trend among the people and using live streaming as a means to interact is social media live streaming Bigo live. The existence of bigo live as an internet community forum (Cyber Community) certainly changes in the norms and values adopted by these users, so it cannot be denied that in the internet community (Cyber Community) there are changes and rules that occur. One of them appears an interaction created virtually in the world, where the emergence of a form of deviation that occurs in social media live streaming bigo live, one of which is cyber sexual harassment. The method used in this study uses visual methods. The theory used in this paper is the theory of routine activities where observations take place and observe every bigo live social media user.
\end{abstract}

Keywords: Bigo Live, Cyber Sexual Harrasment, Live Streaming

\section{Pendahuluan}

Internet atau dunia maya (cyber) merupakan suatu ruang yang diciptakan untuk berinteraksi tanpa adanya pembatas jarak dan waktu (cyber space) dan masyarakat yang menggunakan internet dalam ruang dunia internet disebut masyarakat cyber (cyber community) tiaptiap kelompok masyarakat yang memanfaatkan ruang dunia maya dan mampu berinteraksi baik secara individu maupun kelompok dan proses interaksi yang diciptakan tidak mengharuskan masyarakat untuk berinteraksi secara berhadapan, Tidak terlihat namun dapat dirasakan keberadaannya sebagai bentuk kenyataan yang tak terlihat akan tetapi nyata adanya (Bungin,2005:27). Media sosial hingga saat ini masih terus berkembang dan 
menciptakan inovasi atau perubahan bentuk sarana media interaksi dengan lebih baik. Internet kini sudah menjadi sesuatu hal yang dapat mengubah pola gaya hidup,proses penerimaan penyimpangan,serta pembentukan nilai dan norma di dalam ruang dunia maya (cyber space) itu sendiri.

Saat ini live streaming merupakan suatu inovasi terbaru untuk masyarakat mengeksperiskan diri dan saling betukar pikiran. Media sosial saat ini yang menjadi tren di kalangan masyarakat dan menggunakan cara live streaming sebagai sarana untuk berinteraksi adalah media sosial live streaming Bigo live.

Bigo live merupakan aplikasi yang terbaru dan kian populer, hal itu dikarenakan banyak hal yang menarik masyarakat untuk menggunakan aplikasi tersersebut bagi para penghuni dunia maya. Sementara untuk berbagai komunitas dapat dengan mudah untuk mengekspresikan diri dan saling berkenalan di aplikasi media sosial lewat dunia maya yang akrab dengan perkembangan teknologi terutama kawula muda, Bigo live pun dikenal sebagai aplikasi penyedia layanan streaming online dengan adanya layanan streaming masyarakat dapat dengan mudahnya menginformasikan sesuatu secara cepat dan langsung. (https://jurnalapps.co.id/diakses/11/ $03 /$ 2019).

Dalam pengguna Bigo Live bersifat bebas tanpa batasan yang berisi orang-orang dengan hak penggunaan yang sama. Masyarakat yang menggunakan aplikasi bigo live dapat menerima dan menolak sesuai keinginannya masing-masing baik itu karena alasan pribadi ataupun tidak dan media sosial ini terbuka untuk umum sehingga pengguna media sosial ini dapat memberi kritikan dan komentar serta apresiasi secara langsung disaat penyiar sedang menyiarkan secara langsung. Penyiar dapat melihat dan membaca disaat penyiar sedang menyiarkan, tentu saja pengguna media sosial ini merupakan masyarakat dari dunia nyata yang menyempatkan diri untuk ikut dan melihat sebuah informasi yang diinginkan di dunia maya.

Dengan adanya bigo live sebagai wadah masyarakat internet (cyber community) tentu terjadi perubahan didalam tatanan norma-norma dan nilai -nilai yang dianut oleh para pengguna ini, tidak bisa kita pungkiri bahwa didalam masyarakat internet (cyber community) terdapat suatu perubahan dan aturan yang terjadi. dalam suatu wadah media sosial ini tentu saja memiliki sesuatu yang tidak dapat di hindari.dengan adanya fitur feedback secara langsung yang 
menciptakan ruang interaksi yang secara realistis, maka terjadi suatu interaksi yang dimana penonton (viewers) memberi kritikan dan komentar tanpa disensor atau dibatasi perkataan baik secara lisan maupun tulisan terhadap para penyiar (broadcaster). Hal tersebut merupakan salah satu resiko penyiar dalam menanggapi para penonton (viewers) dimulai dari penyiar menyiarkan secara langsung terdapat penonton yang berkomentar dengan sesuatu yang tidak disukai oleh penyiar bahkan perkataan serta ajakan yang yang berisifat melecehkan (sexual harrasemnt).

Gadis berusia 10-14 tahun bersedia memperlihatkan bentuk tubuh mereka di aplikasi live streaming bigo live demi mengumpulkan poin dari aksi mempertontonkan bagian tubuh yang tertentu sesuai keinginan penonton, jika berhasil mengumpulkan poin yang dijanjikan oleh penonton para penyiar mendapatkan berbentuk hadiah. Ribuan konten vulgar di 11 aplikasi telah diblokir kominfo,dua diantaranyaa dalah Bigo live dan Smule (TribunNews.com/diakses/11/10/2019).

Dapat kita lihat dari sudut pandang kriminologi dimana penyiar di dalam jejaring sosial live streaming bigo live dapat menimbulkan suatu bentuk komunitas penyimpangan di media sosial salah satunya adalah bentuk cyber sexual harrasment.

\section{Penyimpangan Seksual}

$$
\text { Menurut Kartono }
$$

(2009:227) penyimpangan seksual merupakan hal yang bertentangan dengan norma-norma tingkah laku seksual di masyarakat.penyimpangan seksual yang diciptakan dari hal yang tidak sewajarnya berdasarkan fantasi-fantasi seksual yang bertujuan pencapaian orgasme lewat hubungan yang diluar heteroseksual. Proses terjadinya penyimpangan seksual tidak sesuai dan tidak normal di khalayak masyarakat. Hal itu yang mengakibatkan penyimpangan seksual dibentuk berdasarkan asumsi pemikiran yang tidak sesuai di masyarakat.

\section{Cyber crime}

Sejak adanya Convention on Cyber Crime tahun 2001, istilah kejahatan yang berhubungan dengan komputer sering disebut cyber crime. Munculnya beberapa kasus cyber crime di Indonesia, seperti pembajakan kartu kredit, pembajakan beberapa situs, menyadap transmisi data orang lain, dan memanipulasi data dengan cara menyiapkan perintah yang tidak dikehendaki ke dalam program komputer telah membentuk opini publik para pengguna jasa internet bahwa cyber crime merupakan suatu perbuatan yang merugikan 
bahkan amoral. secara analog, kejahatan yang umum terjadi di dunia cyber adalah kejahatan yang berhubungan erat dengan hukum-hukum positif dan kejahatan terhadap moral masyarakat secara umum. Pelanggaran norma susila merupakan pelanggaran yang terbanyak dalam masyarakat dunia maya berhubungan dengan pelangaran norma-norma seksualitas dan pornografi.

Pelanggaran norma seks dan pornografi falam masyarakat maya terjadi dalam skala yang tidak dapat dibatasi,baik melalui penutupan jaringan maupun pemblokiran.

\section{Cyber Community}

Holmes dalam bukunya "Virtual Politics: Identity \& Community Cyberspace” (1997:3) mengungkapkan bahwa ruang maya merupakan dunia dimana terbentuk nilai-nilai budaya (new cultural form) baru yang terbangun melalui interaksi keseharian (daily life interaction) diantara penggunanya melalui mediasi teknologi.

Dalam ruang maya, masyarakat penggunanya membangun dirinya dengan melakukan interaksi dan proses social dalam kehidupan kelompok (jaringan) intra dan antar sesama anggota masyarakat maya. Konstruksi masyarakat maya (cyber community) pada awalnya kecil dan berkembang menggunakan pola jaring labalaba sehingga terbentuklah masyarakat yang besar. Dengan demikian, keberadaan ruang maya selalu terkait dengan komunitas virtual, yaitu mereka yang saling berinteraksi menggunakan teknologi komputer (cyberspace-cyber community),

Komunitas virtual menggunakan jaringan social internet sebagai tempat (space) bertemunya anggota-anggotanya sebagai upaya mempertahan afiliasinya sehingga interaksi dan keterhubungan tersebut dapat terus berlangsung. Dengan demikian, setiap komunitas virtual memiliki budaya kolaboratif yang dibentuk, dipelihara, dipertahankan dan dikembang oleh partisipannya. Budaya ini mempengaruhi bagaimana orang berperilaku di dalamnya, dan orang berinteraksi untuk berbagi nilai, makna dan juga identitas mereka. Inilah mengapa keberadaan komunitas virtual selalu memunculkan budaya virtual, sehingga pembahasan mengenai komunitas maya ini tidak terpisahkan dengan bentukan norma dan tata nilai diantara mereka (cyberculture).

\section{Cyber Sexual Harrasment}

Secara umum yang dimaksud dengan pelecehan seksual dunia maya adalah segala macam bentuk perilaku yang berkonotasi 
atau mengarah kepada hal-hal seksual yang dilakukan secara sepihak dan tidak diharapkan oleh orang yang menjadi sasaran sehingga menimbulkan reaksi negatif seperti malu, marah, benci, tersinggung, dan sebagainya pada diri individu yang menjadi korban pelecehan tersebut yang telah dilakukan di dunia maya.

Rentang pelecehan seksual ini sangat luas, yakni meliputi main mata, siulan nakal, komentar berkonotasi seks atau gender, humor porno, cubitan, colekan, tepukan atau sentuhan di bagian tubuh tertentu, gerakan tertentu atau isyarat yang bersifat seksual, ajakan berkencan dengan iming-iming atau ancaman, ajakan melakukan hubungan seksual hingga perkosaan.

Pelecehan seksual dunia maya bisa terjadi di mana saja dan kapan saja. Meskipun pada umumnya para korban pelecehan seksual adalah kaum wanita, namun hal ini tidak berarti bahwa kaum pria kebal (tidak pernah mengalami) tindak pelecehan. Pelecehan seksual dunia maya bisa terjadi di mana saja dan kapan saja, seperti di bus , pabrik, supermarket, bioskop, kantor, hotel, trotoar, baik siang maupun malam.

Ada lima kategori pelecehan seksual. Pertama pelecehan gender, yang berupa ungkapan verbal atau perilaku merendah- kan gender lain. Misalnya, mengatakan: apa sih yang dapat dikerjakan perempuan dalam kasus semacam ini?. Kedua, seduction berupa rayuan seksual, sensual yang diucapkan secara senonoh, misalkan tiba tiba menelepon mengajak kencan atau menjadikan seseorang sasaran pembicara-an yang mengandung atau dikaitkan dengan hal-hal seksual. Ketiga , bribery merayu dengan disertai upaya "penyuapan”. Misalnya janji akan diberi promosi kenaikan pangkat atau gaji, janji diluluskan ujian . Keempat sexual coercion, memaksa atau mengancam dengan ber-bagai cara agar korban bersedia melakukan apa yang diinginkan . Kelima, sexual imposition berupa perlakuan "menyerang" secara paksa sehingga korban tidak berdaya menolaknya, misalnya tiba-tiba mencium dan mendekap dari belakang. (Suryandaru, 2007:3)

Kontak-kontak yang dilakukan dapat diartikan sebagai salah satu cara menggoda atau berkenalan (flirting), namun juga bisa dapat disebut gangguan (harassment). Kontak yang dilakukan remaja untuk mengenal orang asing di dunia internet semakin mudah dengan menggunakan situs jejaring sosial sebagai media mereka menemukan orang yang ingin mereka kenal (Ningtyas, 2012:38). 


\section{Aktivitas Seksual dalam bentuk} Tindak Pidana Pelacuran/Prostitusi

Pelacuran atau prostitusi adalah pertukaran hubungan seksual dengan uang atau hadiah sebagai suatu transaksi. Perdagangan Pelacuran merupakan cabang dari industri seks yang sejajar dengan pornografi, tari telanjang, bahkan segala mata pencaharian yang berkenaan dengan eksploitasi seksual dan pertunjukan yang berkenaan dengan seksualitas untuk menghibur orang lain demi mendapatkan materi yang dibutuhkan dalam kehidupan.

\section{Aktivitas Seksual dalam bentuk Tindak Pidana Pornografi}

Menurut Pasal 1 Undang-undang Nomor 44 tahun 2008 tentang Pornografi aktivitas seksual dalam Eksploitasi yang dimaksud adalah muatan pornografi yang diperlihatkan atau dipertunjukan dimuka umum yang memuat kecabulan seperti gambar bergerak, gerak tubuh, sketsa, ilustrasi, foto, tulisan, suara, bunyi dan bentuk pesan lainnya yang melanggar norma kesusilaan Menampilkan materi asusila didepan umum maksudnya tindakan yang oleh seseorang sudah mengetahui isi materi yang akan ditampilkan bermuatan asusila atau melanggar kesusilaan masyarakat dengan tujuan agar orang lain mengetahui materi tersebut, artinya jenis tindakan
Eksploitasi Seksual dalam muatan pornografi tersebut berupa hal-hal terkait perilaku seksual yang dipertunjukan dengan sengaja dimuka umum yang memuat kecabulan dengan berbagai macam cara dan bentuk bisa melalui gambar/sketsa, ilustrasi, tulisan, suara, foto dan video gerak tubuh seseorang seperti tarian erotis/striptis.

Eksploitasi dalam pornografi tidaklah dilihat dalam suatu pemahaman sempit mengenai bagaimana aktivitas seksual dan proses keikut sertaan atau keterlibatan perempuan didalamnya. Pada banyak kasus para perempuan yang terlibat dalam aktivitas pornografi kemungkinan besar berangkat dari keinginan/kesadaran sendiri dan tidak dipaksa yang di latarbelakangi banyak faktor, misal masalah ekonomi, ingin terkenal, jalan pintas untuk populer dan sebagainya.

Menurut Pasal 10 Undang-undang Nomor 44 tahun 2008 tentang Pornografi bentuk aktivitas seksual dalam Eksploitasi yang dimaksud adalah bentuk aktivitas dari muatan pornografi yang diperlihatkan atau dipertunjukan dimuka umum yang memuat kecabulan atau bentuk aktivitas yang menggambarkan ketelanjangan dan bentuk aktivitas persenggamaan, artinya yang dimaksud bentuk dari aktivitas seksual dalam pornografi adalah hal-hal terkait 
perilaku seks atau cabul yang dilakukan atau diperlihatkan bisa dengan foto atau video seseorang sedang melakukan persenggamaan atau hubungan intim/alat kelamin. Dalam korelasi terhadap bentuk aktivitas seksual dari muatan Pornografi yang berujung pada kekerasan terhadap perempuan dan menempatkan perempuan sebagai korban, namun pada saat yang bersamaan pornografi memposisikan perempuan sebagai pelaku (kriminalisasi) walau sebenarnya perempuan adalah sebagai korban (reviktimisasi).

\section{Aktivitas Seksual dalam bentuk Tindak Pidana Perdagangan Orang}

Dalam undang-undang Pemberantasan Tindak Pidana Perdagangan Orang tidak menyebutkan secara jelas dan tegas mengenai pegertian bentuk aktivitas dalam eksploitasi. Pengertian eksploitasi seksual yang tercantum di dalam pasal 1 angka 8 hanya memberikan pengertian eksploitasi seksual secara umum tanpa mengerucut kepada penjelasan bentuk aktivitas eksploitasi seksual. "Eksploitasi Seksual adalah segala bentuk pemanfaatan organ tubuh seksual atau organ tubuh lain dari korban untuk mendapatkan keuntungan, termasuk tetapi tidak terbatas pada semua kegiatan pelacuran dan percabulan".
Penjelasan Umum tentang Bentuk Eksploitasi dalam Undang-undang Nomor 21 tahun 2007 tentang Pemberantasan Tindak Pidana Perdagangan Orang meliputi kerja paksa atau pelayanan paksa, perbudakan, dan praktik-praktik serupa perbudakan.

Kerja paksa atau pelayanan paksa adalah kondisi kerja yang timbul melalui cara, rencana, atau pola yang dimaksudkan agar seseorang yakin bahwa jika ia tidak melakukan pekerjaan tertentu, maka ia atau orang yang menjadi tanggungannya akan menderita baik secara fisik maupun psikis. Sedangkan pejelasan bentuk aktivitas dalam Eksploitasi Seksual yang dimaksud dalam penjelasan umum diatas lebih menjelaskan tentang tindakan/ perbuatan seseorang dengan ancaman kekerasan/ penggunaan kekerasan, penjeratan utang atau memberi bayaran atau memanfaatkan keadaan sehingga memperoleh persetujuan dari orang yang memegang kendali atas orang lain agar bisa melakukan Eksploitasi tetapi tidak terbatas pada pelacuran dan percabulan dengan cara memperkerjakan seseorang sebagai pramuria/pemandu karaoke bebas layanan seks, penari bugil/telanjang, penjualan wanita untuk pemuas nafsu seks/ dengan maksud tujuan selalu melakukan aktivitas hubungan seks atau memaksa 
berhubungan intim.Berdasarkan bukti empiris, perempuan dan anak adalah kelompok yang paling banyak menjadi korban tindak pidana perdagangan orang.

\section{Landasan Teori}

\section{Routine Activity Theory}

Holt dan Bossler (2009) menemukan indikasi bahwa gaya hidup dalam cyber space, amat erat pengaruhnya dengan resiko menjadi korban dalam kejahatan online ( Ningtyas. 2012:27).

Selanjutnya, Faktor terjadinya kejahatan di dunia Internet bila dikaitkan dengan teori aktivitas rutin dapat dijelaskan melalui beberapa faktor(Ningtyas. 2012:28):

\section{A. Space (tempat yang memungkinkan} terjadi)

space atau tempat adalah suatu elemen yang penting dalam faktor terjadinya suatu kejahatan atau penyimpangan, media sosial bigo live merupakan suatu jejaring sosial yang diciptakan untuk masyarakat dunia maya untuk melakukan interaksi namun dalam Internet, tempat bisa diartikan sebagai jaringan, yang nantinya akan dibagi-bagi berdasarkan web domain atau alamat jaringan. Disinilah interaksi dalam cyberspace atau ruang Internet berlangsung dengan media.dengan kata lain penyimpangan yang terjadi di media sosial bigo live merupakan tempat atau lokasi peneliti untuk meneliti tindak penyimpangan yang terjadi di komunitas penyimpangan di dalam media sosial live streaming bigo live yang merupakan wadah tempat komunitas penyimpangan tersebut.

Menurut Mesch (2009) adalah "new space activity of youth" atau tempat baru untuk beraktifitas bagi anak-anak muda. Berdasarkan aspek teknologi dan inovasi, internet saat ini menyediakan berbagai kesempatan untuk beraktifitas, termasuk interaksi sosial, serta menghasilkan beberapa kegiatan sosial dan pertemuan orang-orang baru, seperti fungsi dari situs jejaring sosial dan fasilitas layanan chatting.

Sampai dengan saat ini, perkembangan Internet telah membawa individu untuk menunjukkan dan mengembangkan aktifitas reguler mereka. Oleh karena itu, interaksi sosial dalam dunia virtual menjadi suatu gaya hidup (lifestyle) yang bagi sebagian orang menjadi hal yang sangat penting. Pada penelitian ini, space atau tempat yang menjadi objek penelitian adalah situs jejaring sosial live streaming bigo live. Dapat diasumsikan bahwa anak pada usia remaja yang menggunakan bigo live secara berlebihan untuk aktifitas keseharian mereka, dapat membawa mereka menuju 
penyimpangan sosial, seperti cyber sexual harrasment

\section{B. A Capable Guardians} (Perlindungan dan pengawasan yang digunakan)

Setiap aktiftas di internet, sama seperti pada dunia nyata dibutuhkan "a capable guardian" atau perlindungan dan pengawasan yang digunakan untuk mencegah kemungkinan menjadi korban kejahatan dan penyimpangan yang terjadi di dalam media sosial bigo live. Dalam dunia internet, atau cyberspace konsep "a capable guardian" adalah sebagai berikut:

\section{1) Digital Guardians}

Media sosial bigo live memiliki fitur pengaman dan peraturan yang ada sesuai dengan prosedur penggunaan yang layak untuk masyarakat secara umum. Digital guardians adalah upaya pencegahan kejahatan yang dibantu dengan penggunaan teknologi informasi dan komunikasi seperti Firewall, Password, Anti virus, dan Remote computer (Yucedal, 2010). Namun Perlindungan dan penjagaan digital ini masih dapat menciptakan ruang penyimpangan dan tindak kejahatan di dalam media sosial bigo live ini harus ditunjang dengan tingkat wawasan yang baik, dalam konteks pengetahuan pernggunaan internet dari penggunanya.
Penggunaan teknologi ini membutuhkan pengetahuan agar dapat digunakan secara maksimal. Jika menggunakan bigo live tanpa mengerti cara mengamankan diri mereka, dan tidak ada yang memberinya pengetahuan tersebut, maka resiko penyimpangan sosial akan semakin besar.

\section{2) Social Guardians}

Social Guardians adalah upaya pencegahan kejahatan yang dilakukan oleh orang disekeliling kita (orang tua, teman dan masyarkat sekitar). Di dalam media sosial bigo live, Perlindungan dan penjagaan yang berasal dari lingkungan sosial dalam kegiatan online individu, seperti pengawasan dan pertukaram informasi.

Tingkat pengawasan atau perlindungan yang dilakukan oleh lingkungan sosial akan berpengaruh terhadap perilaku individu dalam berinteraksi di dunia virtual (cyberspace), semakin sedikit pengawasan atau perlindungan yang didapat dari lingkungan sosial, maka kemungkinan menjadi korban kejahatan Internet akan makin besar. Pengawasan atau perlindungan yang minim diasumsikan membawa individu rentan menjadi korban dari kejahatan dan penyimpangan virtual. 
selain orang tua, teman sebaya adalah bagian yang terpenting dalam kehidupan sosial mereka, dalam usia remaja, anak cenderung lebih mendengarkan perkataan dan nasihat dari teman dan menghabiskan waktu luang dengan mereka, sehingga jika penggunaan bigo live tidak diawasi oleh orang tua, dan mendapat pengaruh yang buruk dari lingkungan dan teman sepermainan, maka anak berada dalam zona yang rentan.

\section{A Suitable Targets (Mudah menjadi pelaku atau sasaran penyimpangan)}

Didalam media sosial bigo live tidak adanya korban kejahatan . hal itu dikarenakan anggota komunitas media sosial bigo live ini memang murni sebagai wadah untuk masyarakat bertindak atau berperilaku menyimpang. Dengan sistem interaksi secara langsung komunitas ini dapat saling berinteraksi tanpa adanya batasan ucapan dan kurangnya moral serta etika berbicara di masyarakat baik Individu ataupun kelompok, siapa saja dapat menjadi target (a suitable target).

Menurut Alshalan (2006) para pengguna media bigo live sangat rentan untuk menjadi pelaku penyimpangan yang termotivasi (a motivated offender) untuk melakukan penyimpangan, dan juga ketika tidak adanya sistem penjagaan yang tepat (a capable guardian). Kerentanan yang lebih tinggi terjadi ketika individu tidak dapat melindungi informasi atau data personal mereka, sehingga ekspos yang besar tersebut akan membawa mereka kedalam penyimpangan. Dalam media sosial bigo live, yang dapat menjadi faktor mudahnya pelaku penyimpangan.

\section{Motivated Offender (Pelaku yang termotivasi berdasarkan saling membutuhkan)}

Bigo live terdapat penyiar dan penonton, ketika penonton meminta penyiar melakukan tindakan seksual dan memberi hadiah atau apresiasi untuk melakukan sesuatu yang merupakan kejahatan seksual, dan penyiar melakukan apa yang diinginkan penonton untuk mendapatkan keinginannya berupa hadiah tertentu atau sesuatu yang sebenarnya di lakukan tanpa paksaan.

Dalam dunia Internet kejahatan tidak akan terjadi jika tidak adanya kesempatan dan situasi yang mendukung. Kesempatan disini dapat berarti lemahnya penjagaan atau perlindungan dari jaringan (web), atau akun pribadi calon korban. Situasi yang mendukung adalah lokasi terjadinya kejahatan dalam cyberspace atau ruang virtual. 
Lokasi tersebut berbeda dengan kejahatan konvensional, karena pelaku dan korban dapat berada pada tempat yang sama dalam suatu waktu tanpa disadari. Namun terjadinya kejahatannya tidak bersamaan dengan waktu korban sedang berada ditempat tersebut (jaringan). Pelaku dapat melakukan kejahatan ketika korban sedang offline atau tidak aktif dunia virtual. Serta, pelaku potensial untuk melakukan kejahatan sangat mudah muncul di dunia Internet dan tidak akan begitu saja hilang walaupun aksinya sudah diketahui oleh khalayak dunia virtual karena berbagai hal seperti berikut:

1. Kesempatan melakukan kejahatan dalam dunia maya itu tidak terbatas,serta tingkat anonimitas yang begitu besar membuat siapapun dapat menjadi korban serta menjadi "a motivated offender".

2. Pelaku dalam dunia maya sulit ditemukan secara mudah, terkadang korban tidak menyadari kalau ia sedang kontak dengan pelaku.

Aturan dan penghukuman sulit menjerat pelakuInternet adalah tempat terbuka dan bebas, serta tidak ada suatuperaturan ketat, sehingga siapa saja dapat mengaksesnya.relevan bagi kriminologi. Kejahatan, penyimpangan yang terjadi dalam isu ini merupakan kajian kriminologi, dimana dua hal tersebut terjadi di dalam permasalahan penelitian ini, yaitu mengenai realitas Penyimpangaan Sosisal Dalam Konteks Cyber Sexual Harrasement Terhadap Penggunaan Jejaring Sosial Live Streaming Bigo Live.

Pemahaman yang mendalam mengenai masalah ini dengan menggunakan perspektif kriminologi dapat membantu memberikan perbaikan ke depannya mengenai tindakan kejahatan cyber, Penyimpangan, dan kontrol sosial.

\section{Metode Penelitian}

Tipe pada penelitian ini deskriptif kualitaif dimana penulis berusaha untuk menjelaskan serta menjabarkan fenomena yang terjadi dalam penelitian ini.oleh karena itu, pada penelitian ini akan berusaha memahami media sosial live streaming bigo live dalam bentuk wadah yang melakukan penyimpangan. Kemudian dapat dijelaskan secara visual (fotografi dan vidiografi) dimana data yang diperoleh melalui para pengguna akun media sosial bigo live dan kolom chat live streaming tersebut.

\section{Cara Kerja Bigo Live}

Dalam pengunaan media sosial bigo live, pengguna menjadi dua bagian yaitu: 


\section{Penyiar(broadcaster)}

Berdasarkan pengamatan di media sosial live streaming bigo live penyiar yaitu pengguna yang melakukan live streaming untuk menyiarkan aktivitas dirinya secara langsung dan dapat dilihat oleh para pengguna akun media sosial bigo live tanpa adanya batasan penonton yang ingin melihat.

\section{Penonton (viewers)}

Penonton adalah pengguna aplikasi media sosial bigo live yang dimana ketika penyiar (broadcaster) sedang melakukan siaran dan pengguna yang lain dapat masuk dan bergabung ke siaran dengan menonton penyiar yang melakukan live streaming. Penulis juga menemukan bahwa didalam bigo live pengguna akan menemukan channel pengguna aktif yang bisa langsung ditonton dengan cara tap salah satu broadcaster tanpa harus masuk ke room atau sejenisnya. Pengguna tinggal memilih ingin melihat broadcaster sesuai keinginan penonton.

\section{Fitur Pada Media Sosial Bigo Live}

Atas dasar observasi yang ditelusuri oleh penulis, penulis menemukan adanya proses komunikasi pada bigo live sendiri, terdapat proses komunikasi yang dilakukan oleh para penggunanya, mengikut sertakan dalam dalam pembentukan media dan digunakan untuk berbagai tujuan, seperti mengumpulkan banyak beans atau gift dan juga media interaksi dan komunikasi bagi para penyiar dengan penonton, berikut beberapa fitur yang ada di media sosial bigo live.

\section{Menu}

Penulis menemukan,pada awal tampilan home ada banyak pilihan dan banyak pengguna media sosial yang sedang melakukan live streaming dan pengguna dapat memilih sesuai keinginan pengguna.

\section{Identitas}

Disini penulis menemukan identitas pengguna media sosial live streaming bigo live, di dalam media sosial ini pengguna tidak diharuskan menggunakan sesuai dengan identitas asli bahkan beberapa pengguna media sosial ini mengganti nama mereka dengan nama samaran. Dan identitas mereka disertai dengan poto profil yang dimana foto profil juga tidak diharuskan menggunakan foto asli diri.

\section{Beans}

Beans merupakan hasil dari broadcaster melakukan siaran langsung yang dimana para penyiar mendapatkan sejumlah hadiah berupa gift dan gift secara automatis berubah menjadi beans penyiar. 


\section{Jumlah penonton}

Didalam penelitian, penulis menemukan jumlah penonton yang memasuki atau melihat para penyiar (broadcaster) dan mengetahui jumlah yang melihat broadcaster.

\section{5. gift}

Penulis juga menampilkan sejumlah penampilan gift yang dapat di berikan oleh penonton untuk penyiar, viewers arus melakukan top up atau biasa disebut pengisian saldo dan mendapatkan sejumlah diamond yang dapat digunakan berupa debit dan pulsa, dengan jumlah diamond yang diterima penonton dapat memilih dan memberi penyiar berupa gift yang di inginkan.

\section{Tool bar}

Dengan nama akun caroline berdasarkan pengamatan yang dilakukan oleh penulis pada tanggal 16 oktober 2019 penulis membuka salah satu akun secara random yang melakukan live streaming pada pukul 22:43 WIB. Penulis mulai mengamati dengan seksama dan merekam dan merecord pembicaraan penyiar dengan penonton sebagai akun yang melakukan live streaming

Streaming yang dimana penyiar melakukan suatu bentuk penyimpangan seksual berdasarkan keinginan penonton. dapat dilihat pada gambar 5.1 yang dimana penyiar sedang melakuan live streming sedang berbaring tanpa melihatkan wajahnya,salah satu dari penonton yang akunnya bernama @Jendraal yang mengatakan:

“@Jendraal: Desahaaaan an teeh “

Dapat kita lihat bahwa akun yang bernama@Jendraal Menginginkan penyiar untuk melakukan desahan, hal tersebut merupakan salah satu bentuk cyber sexual harrasement, yang dimana ungkapan dan perkataan baik secara lisan dan tulisan mengacu pada suatu bentuk ajakan yang berbau seksual. Berdasarkan keinginan dari penonton maka penyiarpun melakukan apa yang membuat penonton senang.

$$
\text { “....(desahan)" }
$$

Penyiar melakukan keinginan penonton dan mulai mendesah dan berfantasi dengan apa yang ada di sekitarnya, bantal yang dipakai penyiar untuk tidur pun mulai diremas dan di belai oleh penyiar, seakan ingin membuat hasrat para penonton bergejolak penyiar mulai mendekatkan suaranya ke handsfree agar suara yang dihasilkan terdengar jelas oleh penonton, berikut screenshoot yang didapatkan oleh penulis sebagai data visual kriminologi. Dari apa yang dilakukan oleh 
penyiar timbul sebah respon dari penonton yang lain , dimana ID:2994441433 yang mengatakan di kolom chat:

"ID:2994441433 : ayo dong mi pake

kain batik panjang nya dong di kemben"

Disini terlihat muncul sebuah keinginan lain yang diinginkan oleh penonton, dan penonton yang akunnya bernama Rizky Brewok mengatakan:

"knapa itu, sakit perut ya"

Ada beberapa penonton yang tidak mengetahui apa yang terjadi seakan bahwa penyiar mengalami sakit perut. Dengan apa yang telah dilakukan oleh penyiar membuat penonton merasa puas secara seksual akun yang bernama hara memberi gift berupa lonceng yang berjumlah total keseluruhan 10x yang harganya 1 bell $=5$ diamond. Tentu dengan gift yang diberikan penyiar merasa senang akan gift yang telah diberikan dan memberi trimakasih kepada hara sebagai berikut:

" hara thank you.... thank you so much berkah selalu"

Terdapat akun yang bernama kewer2 yang mengatakan:

\footnotetext{
"lbh histeris $\lg \mathrm{y} "$
}

Yang dimana akun yang bernama kewer2 menginginkan lebih histeris lagi.dengan perkataan hal tersebut dapat kita lihat sebuah keinginan penonton tidak terbatas, tidak hanya 1 penonton yang menginginkan hal tersebut akan tetapi banyak penonton yang menginginkan lebih dan dapat melihat serta mendengarnya.

Dengan apa yang telah penulis amati hal tersebut menciptakan sebuah bentuk penyimpangan yang dilakukan baik dari penyiar dan penonton di dalam media sosial live streaming bigo live, hal tersebut dikarenakan saling berketergantungan dengan apa yang diinginkan penonton menginginkan sesuatu hal yang menyimpang dan penyiar menginginkan hadiah dari penonton agar mendapatkan uang. Dengan konteks cyber sexual harrasment yang merupakan sebuah tindak kejahatan di dalam media sosial ini, telah berubah menjadi bentuk suatu tindakan yang menerima sebuah kejahatan menjadi sebuah penyimpangan yang di terima bersama di dalam media bigo live ini. 


\section{Hasil Analisa Dan Pembahasan}

\section{Space (tempat yang memungkinkan terjadinya penyimpangan media bigo live)}

Space atau tempat adalah suatu elemen yang penting dalam faktor terjadinya suatu kejahatan atau penyimpangan, media sosial bigo live merupakan suatu jejaring sosial yang diciptakan untuk masyarakat dunia maya untuk melakukan interaksi namun dalam Internet, tempat bisa diartikan sebagai jaringan, yang nantinya akan dibagi-bagi berdasarkan web domain atau alamat jaringan. Disinilah interaksi dalam cyberspace atau ruang Internet berlangsung dengan media.dengan kata lain penyimpangan yang terjadi di media sosial bigo live merupakan tempat atau lokasi peneliti untuk meneliti tindak penyimpangan yang terjadi di komunitas penyimpangan di dalam media sosial live streaming bigo live yang merupakan wadah tempat komunitas penyimpangan tersebut.

interaksi sosial dalam dunia virtual menjadi suatu gaya hidup (lifestyle) yang bagi sebagian orang menjadi hal yang sangat penting. Pada penelitian ini, space atau tempat yang menjadi objek penelitian adalah situs jejaring sosial live streaming bigo live. Dapat diasumsikan bahwa anak pada usia remaja yang menggunakan bigo live secara berlebihan untuk aktifitas keseharian mereka, dapat membawa mereka menuju penyimpangan sosial, seperti cyber sexual harrasment. hal ini menunjukkan bahwa space atau tempat yang memungkinkan terjadinya penyimpangan dalam konteks ini adalah media sosial bigo live yang merupakan suatu bentuk wadah terjadinya penyimpangan di dunia maya, selayaknya sebuah komunitas yang melakukan sebuah penyimpangan di media sosial ini. Dengan kata lain media bigo live adalah suatu bentuk wadah yang dapat memungkinkan terjadinya penyimpangan.

\section{A Capable Guardians (Perlindungan dan pengawasan yang digunakan)}

Setiap aktiftas di internet, sama seperti pada dunia nyata dibutuhkan "a capable guardian" atau perlindungan dan pengawasan yang digunakan untuk mencegah kemungkinan menjadi korban kejahatan dan penyimpangan yang terjadi di dalam media sosial bigo live. Dalam dunia internet, atau cyberspace konsep "a capable guardian" adalah sebagai berikut:

a) Digital Guardians

Digital guardians adalah upaya pencegahan kejahatan yang dibantu dengan penggunaan teknologi informasi dan komunikasi seperti Firewall, Password, Anti 
virus, dan Remote computer (Yucedal, 2010). Namun Perlindungan dan penjagaan digital ini masih dapat menciptakan ruang penyimpangan dan tindak kejahatan di dalam media sosial bigo live ini harus ditunjang dengan tingkat wawasan yang baik, dalam konteks pengetahuan pernggunaan internet dari penggunanya.Jika menggunakan bigo live tanpa mengerti cara mengamankan diri mereka, dan tidak ada yang memberinya pengetahuan tersebut, maka resiko penyimpangan sosial akan semakin besar.

Berdasarkan observasi pengamatan penulis setiap pengguna akun media sosial bigo live ini harus mendaftar untuk menjadi pengguna media sosial ini, terdapat 3 pilihan yang diberikan oleh media sosial ini $e$ mail,facebook, dan instagram. Hal ini merupakan salah satu syarat untuk menjadi pengguna media sosial bigo live, setelah itu pengguna diharuskan membuat sebuah kata sandi (password) yang dimana bertujuan untuk memproteksi akun pengguna agar tidak dapat dibuka dengan orang lain. Akan tetapi setelah pengguna berhasil mendaftar dari pihak bigo live maka pengguna di tuntun dengan persyaratan dan ketentuan sebagai pengguna bigo live yang dimana hal tersebut merupakan syarat yang diberikan dari pihak perusahaan bigo live.
Pengguna tidak diharuskan menggunakan nama dan foto yang sesuai dengan identitas asli, hal tersebut yang menciptakan sebuah bentuk penyalahgunaan dengan nama dan identitas yang tidak dapat di ketahui di dunia nyata yang menciptakan pengguna media sosial bigo live merasa bebas dan tidak khawatir akan ketahuan.

\section{b) Social Guardians}

Tingkat pengawasan atau perlindungan yang dilakukan oleh lingkungan sosial akan berpengaruh terhadap perilaku individu dalam berinteraksi di dunia virtual (cyberspace), semakin sedikit pengawasan atau perlindungan yang didapat dari lingkungan sosial, maka kemungkinan menjadi korban kejahatan Internet akan makin besar. Pengawasan atau perlindungan yang minim diasumsikan membawa individu rentan menjadi korban dari kejahatan dan penyimpangan virtual.

selain orang tua, teman sebaya adalah bagian yang terpenting dalam kehidupan sosial mereka, dalam usia remaja, anak cenderung lebih mendengarkan perkataan dan nasihat dari teman dan menghabiskan waktu luang dengan mereka, sehingga jika penggunaan bigo live tidak diawasi oleh orang tua, dan mendapat pengaruh yang buruk dari lingkungan dan 
teman sepermainan, maka anak berada dalam zona yang rentan.

Penjagaan atau perlindungan yang berada di masyarakat tentu minim, hal ini dikarenakan penggunaan media sosial bigo live dapat dilakukan dimana saja dan tidak ada larangan atau bantahan untuk melakukan live streaming atau mengakses media sosial ini. Hanya sedikit batasan yang di berikan oleh perusahaan bigo live yaitu dilarangnya merokok,ketidaksopanan,porno,tayangan tidak senonoh atau peanggaran hak cipta tidak diizinkan dan akan di ban.siaran langsung dipantau selama 24jam. Akan tetapi hal tersebut diabaikan sebagai pengguna media sosial bigo live tersebut.

\section{A Suitable Targets (Mudah menjadi pelaku atau sasaran penyimpangan di media bigo live)}

Kerentanan yang lebih tinggi terjadi ketika individu tidak dapat melindungi informasi atau data personal mereka, sehingga ekspos yang besar tersebut akan membawa mereka kedalam penyimpangan. Dalam media sosial bigo live, yang dapat menjadi faktor mudahnya pelaku penyimpangan. Dengan adanya fitur bean yang dapat membuat pengguna meraih keuntungan,maka pengguna berlombalomba untuk mendapatkan keuntungan dan menyampingkan sebuah tindakan yang menyimpang.

Dengan adanya penonton dan penyiar dapat melakukan interaksi secara langsung dan terjadinya sebuah penawaran terhadap sebuah bentuk keinginan penonton terhadap penyiar yang memudahkan menjadi pelaku atau sasaran penyimpangan di media sosial bigo live.

\section{Motivated Offender (Pelaku yang termotivasi berdasarkan saling membutuhkan)}

Bigo live terdapat penyiar dan penonton, ketika penonton meminta penyiar melakukan tindakan seksual dan memberi hadiah atau apresiasi untuk melakukan sesuatu yang merupakan kejahatan seksual, dan penyiar melakukan apa yang diinginkan penonton untuk mendapatkan keinginannya berupa hadiah tertentu atau sesuatu yang sebenarnya di lakukan tanpa paksaan. Hal tersebut yang menjadikan sebuah bentuk penyimpangan yang dilakukan oleh pengguna media sosial bigo live ini. Penonton yang menginginkan sebuah bentuk kepuasan terhadap penyiar dan menjanjikan sebuah bentuk hadiah berupa gift dan penyiar menyanggupi dan melakukan apa yang diinginkan penonton agar mendapatkan sebuah gift dari penonton. 


\section{Kesimpulan}

Berbicara mengenai peran jejaring sosial live streaming bigo live yang dimana memiliki power untuk dapat mempengaruhi masyarakat publik akan tindak penyimpangan dalam bentuk cyber sexual harrasment di dalam media bigo live yang berdasarkan kebebasan berpendapat dan mengutarakan apa yang mau disampaikan baik penonton maupun penyiar serta pengaksesan yang dilakukan dan identitas yang diperlukan tidak berdasarkan data yang valid, hal ini tentu menyebabkan seseorang merasa aman jika pengguna media sosial bigo live melakukan penyimpangan.

Oleh karena itu penulis menganalisa berdasarkan observasi yang bertujuan melihat dan mengumpulkan data yang dibutuhkan oleh penulis serta menganalisa berdasarkan teori yang digunakan oleh penulis yaitu routine activity theory oleh holt dan bossler (2009) menemukan indikasi bahwa gaya hidup dalam cyber space,amat erat pengaruhnya dengan resiko mejadi korban dalam kejahatan online (Ningtyas.2012:27).

Penyimpangan cyber sexual harrasment yang dilakukan di media sosial bigo live dimulai dari penamaan judul penyiar yang melakukan live streaming serta penyiaran yang terjadi dan interaksi antara penyiar dan penonton yang saling membutuhkan, hal ini menciptakan sebuah bentuk tatanan norma yang berubah di dalam media sosial bigo live yang dimana penyimpangan yang terjadi merupakan bentuk keseharian penyiar bersama penontonnya.

Terjadinya suatu bentuk penyimpangan dalam konteks cyber sexual harrasment yang terjadi di media sosial bigo live,minimnya pengawasan dan perlindungan sebagai pengguna media sosial bigo live yang menciptakan bentuk penyimpangan memudahkan pengguna akan target terbentuknya pengguna yang melakukan penyimpangan baru.

\section{Saran}

1. Untuk masyarakat, diharapkan untuk lebih bijak dalam penggunaan dan pemanfaatan media di dalam kehidupan sehari-hari, jangan terlalu mudah dalam penerimaan norma yang jelas merusak kepribadian. Lakukanlah penggunaan yang dimana pemanfaatan yang dilakukan berbentuk positif.

2. Untuk BIGO Tecnology PTE.LTD, lakukanlah bentuk perlindungan atau pengawasan yang lebih intens di dalam media yang diciptakan, batasi perkataan yang layak untuk penonton dan untuk 
penyiar lakukan penghapusan data yang secara permanen hal ini merupakan bentuk efek jera yang menurut penulis layak untuk di terapkan.

3. Untuk Pemerintah kementrian KOMINFO, lakukannlah bentuk perizinan serta pengawasan yang lebih terhadap semua media yang berlaku dan digunakan oleh masyarakat. Selalu memberikan bentuk penyuluhan berupa seruan yang mengajak masyarakat untuk melakukan dan menggunakan media sosial dengan positif,dan bijak

\section{Daftar Pustaka}

Bungin, M. B. (2005). Pornomedia: "Sosiologi Media, Konstruksi SosialTeknologi Telematika dan Perayaan Seks di Media Massa”. Jakarta:Prenada Media.

Kamus Besar Bahasa Indoesia Pusat Bahasa, Edisi keempat, Jakarta, Penerbit PT Gramedia Pustaka Utama.

Karina Ayu Ningtyas. 2012. Hubungan Antara Pola Penggunaan Situs Jejaring Sosial Facebook Dengan Kerentanan Viktimisasi Cyber Harrasment Pada Anak.Fakultas Ilmu Sosial Dan Ilmu Politik Universitas Indonesia

Yayan Sakti Suryandaru.2007. Pelecehan Seksual Melalui Media Massa. Jurusan Ilmu Komunikasi FISIP, Universitas Airlangga, Jl. Airlangga 4-6, Surabaya, 60286, Indonesia

Yucedal,B. 2010. Victimization in cyberspace: an applicaation of routine activity and lifesyle exposure theories. Electronic thesis or disertation . kent state university, 2010.

\section{Undang-undang :}

Undang-undang Pasal 1 Nomor 44 tahun 2008

Undang-undang Pasal 10 Nomor 44 tahun Journal of Cyber Criminology, 2,308333

\section{Internet :}

https://jurnalapps.co.id/ar -bigo-liveitu-1502. diakses padi naret 2019

http://www.tribunnews.com/techno/2019/02/ 06/ribuan-konten-vulgar-di-11-aplikasidiblokir-kominfo-bigo-live-dan-smuledi-antaranya diakses pada 13 maret 2019 